\title{
IMPLEMENTASI PENGELOLAAN SUMBER DAYA ALAM TERHADAP KEHIDUPAN SOSIAL EKONOMI PADA MASYARAKAT PARIWISATA DANTE PINE KABUPATEN ENREKANG
}

\author{
Nur Ariska ${ }^{1}$, Rahman Rahim ${ }^{2}$, Lukman Ismail ${ }^{3}$ \\ ${ }^{1}$ Pendidikan Sosiologi, Universitas Muhammadiyah Makassar \\ Email: nurariska@gmail.ac.id \\ ${ }^{2}$ Pendidikan Sosiologi, Universitas Muhammadiyah Makassar \\ Email: rahmanrahim@unismuh.ac.id \\ ${ }^{3}$ Pendidikan Sosiologi, Universitas Muhammadiyah Makassar \\ Email: lukmanismail@unismuh.ac.id
}

\begin{abstract}
This research aims to (1). Knowing the Implementation of Natural Resource Management Towards Social-Economic Life in the Dante Pine Tourism Community of Enrekang Regency. (2). Knowing the SocialEconomic Impacts Against Natural Resource Management in Dante Pine, Enrekang Regency.

This type of research is a qualitative descriptive research, with the Research Location located around Dante Pine Tourism Object in Lakawan Village, Anggeraja District, Enrekang Regency, snowball sampling determination is the sample obtained through a rolling process from one respondent to another respondent. Data collection methods are by observation, interview, documentation. The data analysis method uses three stages namely, data reduction, data presentation and conclusion drawing / verification.

The results showed that (1). The pine dante attractions have their own attraction for visitors. One of the rides that visitors like on the pine boat is the Zip Bike which is a bicycle ride that is in the form of a rope tied to the tree above 10 meters above ground level. (2). The existence of Dante Pine Tourism has had an impact on the social life and economic impact of the community. Dante Pine has indeed made an impact in their social interactions specifically in the form of competition in running the businesses they live. For the economic impact is reflected in an increase in income towards a better, and the results of the increase in income, they use to meet the needs of everyday life, payment of goods and what they save / save as something positive in the presence of Dante Pine Tourism.
\end{abstract}

Keywords: Implementation, Management and Social Economic Impact.

Abstrak. Penelitian ini bertujuan untuk (1). Mengetahui Implementasi Pengelolaan Sumber Daya Alam Terhadap Kehidupan Sosial Ekonomi Pada Masyarakat Pariwisata Dante Pine Kabupaten Enrekang. (2). Mengetahui Pula Dampak Sosial Ekonomi Terhadap Pengelolaan Sumber Daya AlamPariwisata Dante Pine Kabupaten Enrekang.

Jenis penelitian ini adalah penelitian Deskriftif kualitatif, dengan Lokasi Penelitian berada disekitar Objek Wisata Dante Pine di Kelurahan Lakawan, Kecamatan Anggeraja Kabupaten Enrekang, Penentuan informan secara snowball sampling yaitu sampel yang diperoleh melalui proses bergulir dari satu responden ke responden yang lainnya. Metode pengumpulan data adalah dengan observasi, wawancara, dokumentasi. Metode analisis data menggunakan tiga tahap yaitu, reduksi data, penyajian data dan penarikan kesimpulan/verifikasi.

Hasil penelitian menunjukkan bahwa(1). Tempat wisata dante pine memiliki daya tarik tersendiri bagi pengunjung. Salah satu wahana yang disuakai pengunjung di dante pine adalag Zip Bike yangmerupakan wahana bersepeda yang lintasanya berupa tali yang diikat dipohon diatas ketinggian 10 meter dari perukaan tanah. (2). Keberadaan Wisata Dante Pine telah memberikan dampak pada kehidupan sosial maupun dampak ekonomi masyarakat. Dante Pine memang telah membawa dampak dalam interaksi sosial mereka terkhusus dalam bentuk persaingan dalam menjalankan usaha yang mereka jalani. 
Untuk dampak ekonominya tercermin dalam peningkatan pendapatan kearah yang lebih baik, dan hasil dari peningkatan pendapatan tersebut, mereka gunakan untuk memenuhi kebutuhan hidup sehari-hari, pembayaran barang maupun yang mereka simpan/tabung sebagai sesuatu yang bersifat positif dari keberadaan Wisata Dante Pine.

Keywords: Implementasi, Pengelolaan dan Dampak Sosial Ekonomi.

\section{PENDAHULUAN}

Indonesia merupakan salah satu negara kepulauan terbesar di dunia dan menyimpan kekayaan sumber daya alam yang melimpah, baik di darat maupun di laut. Pemanfaatan sumber daya alam di Indonesia baik itu hayati maupun non hayati tidak lain adalah utuk memenuhi kebutuhan hidup dan kesejahteraan hidup manusia

Dipilihnya pariwisata sebagai salah satu sumber devisa karena pariwisata dianggap sebagai “ industri tanpa cerobong asap "yang berarti bahaya maupun kerungian yang ditimbulkannya relatif kecil apabila dibandingkan dengan industri-indutri lainnya yang padat teknologi. Namun demikian tidak berarti bahwa pariwisata tidak mandatangkan bahaya yang dapat menimbulkan resiko. Salah satu resiko yang dihadapi industri pariwisata adalah perubahan kebudayaan masyarakat sekitar obyek wisata akibat pengaruh kebudayaan yang dibawah oleh masyarakat pendatang maupun wisatawan.

Pembangunan dan pengembangan suatu objek wisata yang dilakukan dengan baik akan menghasilkan pendapatan ekonomi yang baik juga untuk komunitas setempat. suatu tempat wisata yang direncanakan dengan baik, tidak hanya memberikan keuntungan ekonomi yang memperbaiki taraf, kualitas dan pola hidup komunitas setempat, tetapi juga meningkatkan dan pemeliharaan lingkungan yang lebih baik. Pariwisata dapat memberikan keuntungan bagi wisatawan maupun komunitas tuan rumah dan dapat menaikkan taraf hidup melalui keuntungan secara ekonomi yang di bawah ke kawasan tersebut.

Sebagai Kabupaten yang dikelilingi pegunungan, Kabupaten Enrekang tentu memiliki berbagai objek wisata yang eksotis dan Asyik untuk berfoto. Kabupaten yang berbatasan langsung dengan Kabupaten Tana Toraja ini menawarkan pemandangan yang cantik dan menakjubkan. Salah satunya Obyek wisata alam Dante Pine Yang terletak di Lingkungan Puncak Lakawan, Kecamatan Anggeraja, Kabupaten Enrekang, Silawesi Selatan. Objek wisata Dante Pine ini Berjarak sekitar 25 km dari Kota Enrekang.

\section{METODE PENELITIAN}

Jenis penelitian dalam penelitian ini adalah penelitian deskriptif kualitatif dengan pendekatan fenomenologi. Dalam penelitian kualitatif pengumpulan data tidak dipandu oleh teori, tetapi dipandu oleh fakta-fakta yang ditemukan pada saat dilapangan oleh karena itu analisis data yang dilakukan bersifat induktif berdasarkan fakta-fakta yang ditemukan yang kemudian dikonstruksikan menjadi hipotetsis dan teori. Fokus penelitian ini adalah implementasi pengelolaan sumber daya alam terhadap kehidupan sosial ekonomi pada masyarakat Pariwiata Dante Pine Kabupaten Enrekang. Penelitian ini dilaksanakan di Kelurahan Lakawan Kecamatan Anggeraja Kabupaten Enrekang.

Yang menjadi sasaran dalam penelitian ini adalah pengelola pariwisata Dante Pine, Masyarakat Sekitar, Dan juga Pengunjung. Dalam penelitian, tetnik penentuan informan dengan menggunakan teknik Snowball Sampling, yang merupakan penentuan pertama-tama dipilih satu atau dua orang tetapi karena dengan dua orang ini belum merasa lengkap dengan data yang diberikan dua orang sebelumnya, begitu seterusnya. Jenis data dalam penelitian ini yakni Data primer (langsung terhadap objek) dan data sekunder (diperoleh melalui media). Adapun teknik pengumpulan data yang dilakukan dalam penelitian ini adalah: observasi, wawancara dan dokumentasi. 


\section{HASIL DAN PEMBAHASAN}

Setelah melakukan observasi, wawancara dan dokumentasi dilapangan, maka akan disajikan data-data yang diperoleh dari penelitian. Untuk lebih jelasnya dapat dilihat sebagai berikut :

\section{a. Pengelolaan wisata dante pine}

\section{Kepemilikan tanah}

Dari hasil wawancara dengan Pengelola Wisata Dante Pine, dapat diketahui bahwa Kawasan wisata Dante Pine adalah milik kehutanan dan sementara diurus kepemilikannya. Dalah hal ini, pemerintah memberi dukungan peneuh kepada pengelola dalam mengambangkan kawasan wisata alam tersebut.

\section{Sarana dan prasarana}

Dari hasil wawancara dengan informan, dapat diketahui bahwa pengelola Wisata Dante Pine menyiapkan beragam Fasilitas umum yakni toilet dan juga musholah bagi yang ingin menunaikan ibadah. Tidak hanya itu, juga terdapat tempat berkemah bagi yang ingi berkemah dibawah pohon pinus lengkap denga fasilitas seperti tenda dan perlengkapan berkemah lainnya. Dante Pine juga menyediakan sebuah kedai kopi khas Enrekang yang berada daam kawasan wisata Dante Pine.

\section{Tenaga kerja}

Dari Hasil wawancara dengan informan, dapat diketahui bahwa jumlah tenaga kerja yang ada di Wisata Dante Pine hanya sekitar 15 orang. Dalam merekrut anggota, menurut informan bahwa hanya mereka yang memiliki keterampilan serta pengalaman yang bergabung dalam mengelola Dante Pine jadi tidak semua orang bisa bergabung dalam mengelola Dante Pine.

\section{Publikasi Wisata Dante Pine}

Dalam proses publikasi Wisata Dante Pine, diketahui bahwa informan yang merupakan komunikator yang memberikan pesan atau informasi kepada orang banyak melalui akun instagram @dante.pine serta akun instagram @kampong_massenrempulu, maka potensi wisata Dante Pine di Kabupaten Enrekang ini dapat di Eksplor sehingga berdampak kepada tingkat kunjungan wisatawan di Dante Pine.

\section{b. Dampak sosial ekonomi pengelolaan Wisata Dante Pine}

Pengelolaan sumber daya alam menjadi sebuah tempat wisata tentu membawa dampak bagi kehidupan sosial masyarakat yang terlibat didalamnya. Untuk lebih jelanya dapat dilihat sebagai berikut:

\section{Pesaingan}

Salah satu perubahan yang dirasakan oleh masyarakat sekitar adalah adanya bentuk persaingan antara masyarakat yang membuka usaha berdagang disekitar Dante Pine terkhusus dalam menjalankan usaha yang mereka tekuni.

\section{Kerja Sama}

Temuan dari hasil wawancara dengan masyarakat ialah meskipun kebberadaan dante pine teleh membawa dampak sosial yang mengakibatkan adanya persaingan namun kerja sama dan saling membantu antar sesama masyarakat dan bahkan dengan pengelola Dante Pine masih bisa terjadi. Dengan terjalinya kerja sama antar sesama masyarakat, maupun masyarakat dengan pihak Dante Pine diharapkan dapat tetap dipertahankan dan tujuan daru kedua belah pihak yang bekerja sama dapat tercapai.

\section{Peningkatan pendapatan}

Mengenai pendapatan mayarakat sekitar Dante Pine, baik itu pengelola, maupun masyarakat sekitar yang membuka usaha berdagang disekitar wisata Dante Pine sangat terlihat dan mereka merasakan dampaknya. Bahwa keberadaan wisata Dante Pine telah 
membawa dampak positif bagi kehidupan perekonomian karena semenjak adanya wisata Dante Pine adanya oeningkatan pendapatan dan juga pekuang kerja sekaligis sebagai alat untuk mengembangkan usaha yang mereka miliki.

\section{Adanya Investasi/Tabungan}

Sebagai efek dari meningkatnya pendapatan masyarakat sekitar Wisata Dante Pine, terdapat bentuk tabungan maupun investasi yang dimiliki oleh mereka yang memiliki usaha berdagang disekitar Dante pine maupun pengelola Dante Pine itu sendiri.

\section{KESIMPULAN}

1. Tempat wisata Dante Pine di Kabupaten Enrekang ini memiliki daya tarik tersendiri bagi wisatawan untuk datang berkunjung. Selain menyajikan pemandangan yang inda, juga terdapat beberapa wahan menantang. Salah satu wahana yang banyak disukai oleh pengunjung Dante Pine Adalah Zip Bike. Zip Bike ini merupakan wahana bersepeda yang lintasannya berupa tali yang diikat di dua pohon pinus diatas ketinggian $10 \mathrm{~m}$ dari tanah.

2. Dampak dari keberadaan wisata dante pine dapat dilihat dari adanya perubahan dalam bentuk interaksi sosial dengan orang-orang baru. Sedangkan bagi masyarakata sekitar yang membuka usaha berdagang disekitar tempat wisata tersebut, semenjak adanya Dante Pine memang telah membawa dampak dalam interaksi sosial mereka terkhusus dalam bentuk persaingan dalam menjalankan usaha yang mereka jalani.

3. Sedangkan dampak ekonomi yang dirasakan masyarakat semenjak adanya wisata Dante Pine, yaitu pendapatan yang mengalami peningkatan,dan sebagai efek dari peningkatan pendapatan tersebut adalah adanya tabungan atau investasi masyarakat.

\section{DAFTAR PUSTAKA}

Devi, Angga Herlin. 2017. Pengembangan Objek dan Daya Tarik Wisata Alam Sebagai Daerah Tujuan Wisata Di Kabupaten Karanganyar. Jurnal Sosiologi DILEMA. 32(1):34-44.

Marliastri,S. 2015. Dampak Sosial Ekonomi Masyarakat Terhadap Obyek Wisata Maros Water Park Pattunuang Isue Kabupaten Maros. Makassar: Skripsi Fakultas Keguruan dan Ilmu Pendidikan Universitas Muhammadiyah Makassar.

Nursalam. 2016.Teori Sosiologi Klasik, Modern, Postmodern, Saintifik, Hermaneutik. Yogyakarta. Penerbit Writig Revolution.

Riswandi. 2015. Dampak Sosial Wisata Pantai Galesong Kabupaten Takalar. Makassar: Skripsi Fakultas Keguruan dan Ilmu pendidikan Universitas Muhammadiyah Makassar.

Risfaisal. 2013. Perubahan Sosial Budaya Pada Masyarakat Adat Ammaoa Kajang. Makassar: Tesis Pasca Sarjana Universitas Negeri Makassar.

Bagus, Denny.2009. dampak pengembangan obyek wisata. http://jurnalsdm.blogspot.com/2009/08/dampak-pengembangan-obyek-wisata.dampak.html\#. (online) di akses pada tanggal 1 Januari 2019

Dammar, Swarni.2018. eksotisme wisata alam dante pine. http://www.google.co.id/amp/s/makassar.sindonews.com/newsread/8238/7/eksotismewisata-alam-dante-pine-enrekang-nan-memukau-1524290654. (online). Diakses tanggal 15 Januari 2019.

Havis Amran's. 2015. Pengertian sumber daya Alam. https://apitswar.wordpress.com//pengertiansumber-daya-alam-dan-jenisnya/. (online) Diakses tanggal 5 Januari 2019.

Madebayu. 2009. Dampak sosial pengembangan wisata. http://10/dampak-sosial-pengembanganpariwisata-terhadap-masyarakat-dikawasan-tanjungbenoa. (online) diakses pada 15 Januari 2019.

Nur Fatih, 2016. seputar pengertian umum. http://seputar-pengertian-umumblogspot.com/2016/0/ pengertian-defenisi-pariwisata.html/m=1 . (online)

di akses tangga 13 Februari 2019. 
Teropong. 2017. Pengertian sumber daya alam. https://formteropong.id/2017/10/16/pengertiansumber-daya-alam-klasifikasi-jenispengelolaan-pemanfaatan-sumber-daya-alam-danhambatannya/. (online) di akses tanggal 14 Februari 2019.

Parepos. Fajar. 2019. Potensi ekonomi kabupaten enrekang.http://parepos.fajar.co.id/2019/06/melirik-potensi-ekonomikabupatenenrekang/.(online) diakses tanggal 09 Februari 2019. 